\title{
Perancangan Pemecah Gelombang di Pantai Auki Kabupaten Biak Numfor Papua
}

\author{
Ixsus Alexander Sappetau ${ }^{\star 1}$, Benyamin Tanan ${ }^{\star 2}$, Erni Rante Bungin ${ }^{\star 3}$ \\ *1 Mahasiswa Program Studi Teknik Sipil, Universitas Kristen Indonesia Paulus, Makassar, Indonesia \\ ixsusalex@gmail.com \\ ${ }^{\star 2 * 3}$ Dosen Program Studi Teknik Sipil, Universitas Kristen Indonesia Paulus, Makassar, Indonesia \\ nyamintan2002@yahoo.com dan erni bungin@yahoo.com
}

\begin{abstract}
ABSTRAK
Penelitian ini bertujuan untuk pencegahan abrasi dengan pemecah gelombang di Pantai Auki. Penelitian ini dapat digunakan sebagai bahan pertimbangan untuk pembangunan gelombang pecah di sekitar pantai. Terlalu besarnya gelombang yang ada di Pantai Auki menyebabkan mundurnya garis pantai akibat abrasi yang mengancam keselamatan jiwa penduduk di daerah tersebut. Data angin dianalisis dengan aplikasi Wind Rose untuk mengetahui arah datang angin dominan. Peramalan gelombang berdasarkan angin dominan dan panjang fetch mengacu pada Shore Protection Manual (SPM) 1984. Penentuan gelombang rencana digunakan metode distribusi gumbell (Fisher Tipped Type I) dengan periode ulang 2-100 tahun dan untuk perencanaan pemecah gelombang (Breakwater) mengacu pada persamaan - persamaan dalam buku Perencanaan Bangunan Pantai. Hasil penelitian menunjukkan arah angin dominan berasal dari arah Barat Daya dengan kecepatan 18 knot. Tinggi gelombang rencana pada periode ulang 50 tahun adalah 2,464 m. Pemecah gelombang direncakan pada jarak $152,5 \mathrm{~m}$ dari garis pantai dengan kedalaman $-3,195 \mathrm{~m}$. Tipe pemecah gelombang yang digunakan adalah pemecah gelombang sisi miring dengan tinggi 7,186 $\mathrm{m}$ dan tebal lapis lindung 4,531 m untuk pencegahan abrasi pantai.
\end{abstract}

Kata Kunci : angin, pemecah gelombang, Gumbell

\begin{abstract}
This study aims to prevent abrasion with a breakwater at Auki Beach. This research can be used as a consideration for the construction of breaking waves around the coast. The too big waves on Auki Beach caused the retreat of the coastline due to abrasion that threatened the lives of residents in the area. Wind data were analyzed with the Wind Rose application to determine the direction of the dominant wind. Forecasting waves based on dominant wind and fetch length refers to the Shore Protection Manual (SPM) 1984. The determination of the plan wave uses the Gumbell's distribution method (Fisher Tipped Type I) with a return period of $2-100$ years and for the breakwater planning refers to the equation - equations in the Beach Building Planning book. The results showed that the dominant wind direction came from the Southwest with a speed of 18 knots. The design wave height for the 50 years return period is $2.464 \mathrm{~m}$. The breakwater is planned at a distance of $152.5 \mathrm{~m}$ from the coastline with a depth of $-3.195 \mathrm{~m}$. The type of breakwater used is an oblique sided breakwater with a height of $7.186 \mathrm{~m}$ and a thickness of $4.531 \mathrm{~m}$ of protection layer to prevent coastal abrasion.
\end{abstract}

Keywords: wind, breakwater, Gumbell

\section{PENDAHULUAN}

Pantai Auki memiliki konfigurasi permukaan tanah yang relatif datar dan bergelombang dengan kemiringan antara $0-5 \%$. Gelombang tertinggi biasanya terjadi pada bulan Mei dan Juli, tinggi gelombang di Pantai Auki ini berkisar antara 1,12 m - 1,21 m. Pada musim tertentu sering terjadi hantaman gelombang laut yang menyebabkan abrasi pantai yang mengakibatkan mundurnya garis pantai dan gelombang pasang yang menyebabkan dibeberapa tempat di kawasan ini mengalami genangan air laut setinggi $\pm 70 \mathrm{~cm}$ dan sejauh \pm 85 $\mathrm{m}$ dari garis pantai, kondisi ini sangat menggangu aktivitas warga dan mengakibatkan rusaknya sarana dan prasarana seperti rumah penduduk, sekolah dant 
empat ibadah. Sekitar 86\% rumah tangga di Distrik Padaido memiliki mata pencaharian sebagai nelayan.

Tujuan penelitian untuk menganalisis karakteristik angin dan gelombang pada wilayah perairan Pantai Auki, serta Merancangkan dimensi pemecah gelombang (Breakwater).

Penelitian ini dilakukan mulai dari bulan April 2019 hingga Mei 2019.

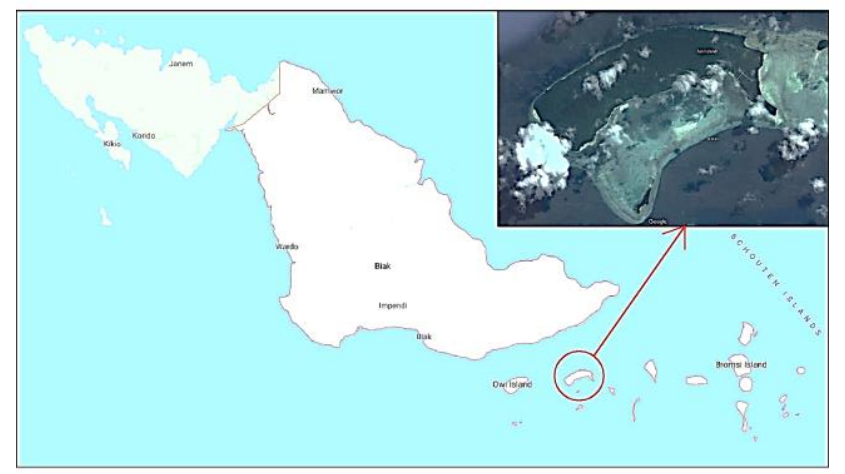

Gambar 1 . Lokasi penelitian

Beberapa penelitian sejenis yaitu pada perencanaan pembangunan breakwater di Pelabuhan Teluk Sololo diperoleh panjang garis pengaruh arah gelombang (fetch effective max) $3.470,62 \mathrm{~m}$, tinggi gelombang signifikan (hs) $0,988 \mathrm{~m}$, dan periode gelombang (ts) 5,374 detik. yaitu elevasi puncak breakwater (et) 2,25 $\mathrm{m}$, tinggi breakwater $(\mathrm{hb}) 14,75 \mathrm{~m}$, berat butir lapis lindung (w) $0,948 \mathrm{~m}$, berat butir lapis lindung (w) 0,948 ton, lebar puncak breakwater (b) $2,449 \mathrm{~m}$, tebal lapis dinding (t) $1,633 \mathrm{~m}$, jumlah batu pelindung (n) 29 buah, dan diameter batu pelindung (d) $0,526 \mathrm{~m}$. Kontrol guling bangunan breakwater yaitu memiliki nilai faktor keamanan sebesar 1,78 yang lebih besar dari batas minimum faktor keamanan yang dizinkan yaitu 1,25 [1], Pada Teluk Sumbreng kejadian angin dominan selama 5 tahun berasal dari Arah Tenggara. $\mathrm{K}$ dan hasil peramalan tinggi gelombang maksimum adalah 4.12 meter dan periode 12.091 detik, sedangkan untuk periode ulang 50 tahun tinggi gelombang 3.482 meter dan periode 11.116 detik [2]. Perencanaan breakwater sisi miring di Pelabuhan Merak menggunakan tetrapod dan batu pecah dengan kemiringan 1:2 [3], gelombang pada Pantai Tapak Paderi dengan kondisi fully developed seas menggunakan breakwater tipe tegak [4], breakwater yang direncanakan untuk mengatasi masalah pengikisan tebing pantai oleh gelombang di Pantai Desa Botubarani yait tipe rubble mound [5]. Perencanaan breakwater di Pantai Jasri yaitu Elevasi puncak adalah $+1.425 \mathrm{~m}$, lebar puncak adalah 2.53 $\mathrm{m}$. Berat butir lapis lindung adalah $1280 \mathrm{~kg}$, lapis kedua $128 \mathrm{~kg}$, lapis ketiga $4 \sim 7 \mathrm{~kg}$. Tinggi fondasi adalah $1.174 \mathrm{~m}$, lebar fondasi adalah $1.174 \mathrm{~m}$ [6].

\section{METODE}

\section{Faktor Tegangan Angin}

Dalam menentukan faktor tegangan angin dilakukan pengolaan data angin dengan memperhitungkan beberapa faktor sebagai berikut:

Menghitung kecepatan angin yang dikoreksi pada ketinggian $10 \mathrm{~m}$

$U_{10}=U_{z}\left(\frac{10}{z}\right)^{\frac{1}{7}}$

Dimana:

$U_{10} \quad=$ Kecepatan angin pada elevasi 10 meter

$U_{z} \quad=$ data kecepatan angin yang diukur pada elevasi $z(z<10 \mathrm{~m})$

Menghitung kecepatan angin laut yang dikoreksi terhadap angin darat

$$
U=R_{T} \cdot R_{L} \cdot U_{10}
$$

Dimana:

$R_{T} \quad=$ Faktor koreksi stabilitas (merupakan fungsi perbedaan temperatur antara udara dan laut)

$R_{L} \quad=$ Faktor koreksi lokasi

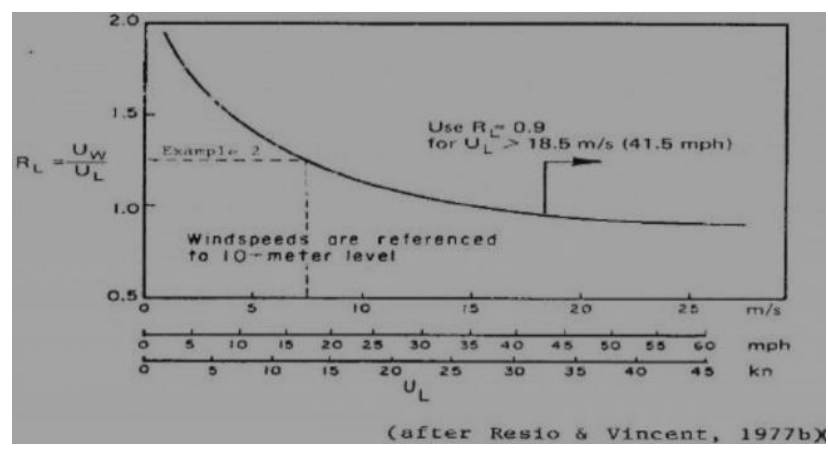

Gambar 2. Faktor koreksi lokasi

Untuk mengkonversi kecepatan angin ada beberapa cara yaitu sebagai berikut :

Jika $U$ dalam satuan $\mathrm{m} / \mathrm{s}$, maka :

$U_{A}=0,71 \times U^{1.23}$

Jika $U$ dalam satuan mph, maka :

$U_{A}=0,589 \times U^{1.23}$

Jika $U$ dalam satuan knot, maka :

$U_{A}=0,698 \times U^{1.23}$

\section{Fetch}

Fetch rerata efektif diberikan persamaan sebagai berikut:

Feff $=\frac{\Sigma X i \cos \alpha}{\Sigma \cos \alpha}$

Dengan: 
Feff $=$ Fetch rerata efektif

$\mathrm{Xi} \quad=$ Panjang segmen fetch yang diukur dari titik observasi gelombang ke ujung akhir fetch

$\alpha=$ Defiasi pada kedua sisi dari arah angin, dengan menggunakan pertambahan $5^{\circ}$.

\section{Peramalan Gelombang di Dalam Laut}

Ada 3 rumus yang digunakan dalam peramalan gelombang dengan cara empiris yaitu sebagai berikut

$\frac{g H_{m 0}}{U_{A^{2}}}=0,0016 x\left(\frac{g F}{U_{A^{2}}}\right)^{1 / 2} \leq 0,24339$

$\frac{g T_{P}}{U_{A}}=0,2857 \times\left(\frac{g F}{U_{A^{2}}}\right)^{\frac{1}{3}} \quad \leq 8,134$

$\frac{g t}{U_{A}}=68,8 \times\left(\frac{g F}{U_{A^{2}}}\right)^{\frac{2}{3}} \quad \leq 7,15 \times 10^{4}$

\section{Dengan:}

$F \quad=$ panjang fetch rata-rata efektif $(m)$

$H_{m 0} \quad$ =tinggi gelombang signifikan berdasarkan

Spectrum/ tinggi gelombang di laut dalam $(m)$

$T p \quad=$ periode puncak spectrum (detik)

$U_{A} \quad=$ wind stress factor $(\mathrm{m} /$ detik $)$

$t \quad=$ durasi angin (detik)

$g \quad=$ percepatan gravitasi $\left(9,81 \mathrm{~m} /\right.$ detik $\left.^{2}\right)$

Menghitung Fully Develop dan Non-Fully Develop

$\frac{g t}{U_{A}}>7,15 \times 10^{4}$, berarti fully develop

$\frac{g t}{U_{A}} \leq 7,15 \times 10^{4}$, berarti non-fully develop

Nilai durasi kritis (tc)

Untuk kondisi fully develop,

$t_{c}=7,15 \times 10^{4} \times\left(\frac{U_{A}}{g}\right)$

Untuk kondisi non-fully develop,

$t_{c}=68,8 \times\left(\frac{g F}{U_{A}{ }^{2}}\right)^{2 / 3} \times \frac{U_{A}}{g}$

Menghitung Fetch Minimum (Fmin)

$F_{\text {min }}=\left(\frac{g t}{68,8 \times U_{A}}\right)^{3 / 2} \times \frac{U_{A}{ }^{2}}{g}$

Menghitung nilai $H_{m 0}$ dan $T_{p}$ :

Kondisi fully develop :

Jika $\mathrm{t} \geq \mathrm{tc}$ (fetch limited), maka :

$H_{m 0}=0,2433 \times\left(\frac{U_{A}^{2}}{g}\right)$

$T_{P}=8,134 \times\left(\frac{U_{A}}{g}\right)$

Jika $\mathrm{t}<\mathrm{tc}$ (duration limited), maka:

$H_{m 0}=0,0016 \times \frac{U_{A}^{2}}{g}\left(\frac{g F_{\min }}{U_{A^{2}}}\right)^{1 / 2}$

$T_{P}=0,2857 \times \frac{U_{A}}{g}\left(\frac{g F_{\min }}{U_{A^{2}}}\right)^{1 / 3}$
Kondisi non-fully develop:

Jika $\mathrm{t} \geq \mathrm{tc}$ (fetch limited), maka :

$H_{m 0}=0,0016 \times \frac{U_{A}^{2}}{g}\left(\frac{g F}{U_{A^{2}}}\right)^{1 / 2}$

$T_{P}=0,2857 \times \frac{U_{A}}{g}\left(\frac{g F}{U_{A^{2}}}\right)^{1 / 3}$

\section{Perkiraan Gelombang}

Fungsi distribusi probabilitas

Metode Distribusi Fisher-Tiiett Type 1 (Distribusi Gumbel 1) digunakan untuk memprediksi gelombang.

$\mathrm{P}\left(H_{s} \leq \hat{\mathrm{H}}_{s}\right)=e^{-c}-\left(\frac{\hat{\mathrm{H}}_{\mathrm{S}^{-}} B}{A}\right)$

Dengan:

$H_{s}$
$\hat{\mathrm{H}}_{s}$ : Tinggi gelombang respresentatif, : Tinggi gelombang dengan nilai tertentu,

$\mathrm{P}\left(H_{s} \leq \hat{\mathrm{H}}_{s}\right) \quad$ : Probabilitas bahwa $\hat{\mathrm{H}}_{s}$ tidak dilampaui,

A

$B$

: Parameter skala,

: Parameter lokasi.

Menghitung distribusi gelombang dengan mengurutkan data dari yang besar ke yang kecil:

Distribusi Fisher-Tippet Type I:

$\mathrm{P}\left(H_{s} \leq S_{s m}\right)=1-\frac{m-0,44}{N_{r}+0,12}$

Dengan:

$H_{s m} \quad$ : Tinggi gelombang urutan ke- $m$

$\mathrm{P}\left(H_{s} \leq H_{s m}\right)$ : Probabilitas dari tinggi gelombang

$m$ : nomor urut tinggi gelombang signifikan $=1,2, \ldots, \mathrm{n}$

$N_{r} \quad$ : Jumlah kejadian gelombang selama pencatatan.

$\hat{\mathrm{H}}_{s m}=\hat{\mathrm{A}} y_{m}+B$

Distribusi Fisher-Tippet Type I:

$y_{m}=-\ln \left\{-\ln P\left(H_{s} \leq H_{s m}\right)\right\}$

Dengan $\hat{A}$ dan $B^{\wedge}$ adalah perkiraan dari parameter skala dan lokal yang diperoleh dari analisis regresi linier.

\section{Menghitung Periode Ulang}

Tinggi gelombang dihitung dari fungsi distribusi probabilitas dengan rumus berikut ini:

$H_{s r}=\hat{\mathrm{A}} y_{r}{ }^{\wedge} \mathrm{B}$

Dengan $y_{r}$ didapat dari persamaan berikut ini :

Distribusi Fisher-Tippet Type l:

$y_{r}=-\ln \left\{-\ln \left(1-\frac{1}{L T}\right)\right\}$

Dengan: 
$H_{s r}$ : tinggi gelombang signifikan dengan periode ulang $T_{r}$

$T_{r}$ : periode ulang (tahun)

$K$ : panjang data (tahun)

$L$ : rerata jumlah kejadian per tahun

\section{Gelombang Pecah}

Jika gelombang menjalar dari tempat yang dalam menuju ke tempat yang sempit yang makin lama makin dangkal, pada suatu lokasi tertentu gelombang tersebut akan pecah. Kondisi gelombang pecah tegantung pada kemiringan dasar pantai dan kecuraman gelombang. Tinggi gelombang pecah dapat dihitung dengan rumus berikut ini:

$\frac{H_{b}}{H^{\prime} 0}=\frac{1}{3,3\left(\frac{H^{\prime} 0}{L_{0}}\right)^{1 / 3}}$

Kedalaman air dimana gelombang pecah diberikan oleh rumus berikut:

$\frac{d_{b}}{H_{b}}=\frac{1}{b-\left(\frac{a H_{b}}{g T^{2}}\right)}$

Dimana $a$ dan $b$ merupakan fungsi kemiringan pantai $m$ dan diberikan oleh persamaan berikut:

$a=43,57\left(1-e^{-19 m}\right)$

$b=\frac{1.56}{\left(1+e^{-19.5 m}\right)}$

Catatan: Untuk mendapatkan nilai $m$ dihitung dari kemiringan dasar pantai

\section{Pemecah Gelombang}

Run up gelombang dapat ditentukan dengan cara mengetahui bilangan Irribaren sebagai berikut:

$I \mathrm{r}=\frac{\operatorname{tg} \theta}{\left(\frac{H}{L o}\right)^{0,5}}$

\section{Dengan:}

Ir $\quad=$ bilangan Irribaren

$\Theta \quad=$ sudut kemiringan sisi pemecah gelombang

$H=$ Tinggi Gelombang di lokasi bangunan

Lo = panjang gelombang di laut dalam

\section{Lebar puncak pemecah gelombang}

$B=n k_{\Delta}\left(\frac{W}{\gamma_{r}}\right)^{1 / 3}$

Dengan:

$$
\begin{array}{ll}
B & =\text { Lebar puncak } \\
n & =\text { Jumlah butir batu } \\
k_{\Delta} & =\text { Koef. Lapis } \\
W & =\text { berat butir batu pelindung } \\
\gamma_{r} & =\text { berat jenis batu pelindung }
\end{array}
$$

\section{Stabilitas unit lapis lindung beton}

$$
\begin{aligned}
& W=\frac{\gamma_{r} H^{3}}{K \mathrm{D}(S r-1)^{3} \cot \theta} \\
& S_{r}=\frac{\gamma_{r}}{\gamma_{a}}
\end{aligned}
$$

\section{Dengan:}

$W \quad=$ Berat butir batu pelindung

$\gamma_{r} \quad=$ Berat Jenis Batu

$\gamma_{a} \quad=$ Berat Jenis Air Laut

$H \quad$ = tinggi gelombang rencana

$\theta \quad=$ Sudut kemiringan sisi pemecah gelombang

$K_{D} \quad=$ Koefisien stabilitas yang tergantung pada bentuk pelindung

\begin{tabular}{|c|c|c|c|c|c|c|}
\hline \multicolumn{7}{|c|}{ Persentase Frekuensi Kejadian Angin (\%) } \\
\hline \multirow[t]{2}{*}{ Arah } & \multicolumn{5}{|c|}{ Kecepatan (knot) } & \multirow[t]{2}{*}{ Jumlah } \\
\hline & $<5$ & $5-10$ & $\begin{array}{c}10- \\
15\end{array}$ & $\begin{array}{c}15- \\
20\end{array}$ & $>20$ & \\
\hline Utara & $0.00 \%$ & $0.00 \%$ & $0.00 \%$ & $0.00 \%$ & $0.00 \%$ & $0.00 \%$ \\
\hline $\begin{array}{l}\text { Timur } \\
\text { Laut }\end{array}$ & $0.00 \%$ & $0.00 \%$ & $0.00 \%$ & $0.00 \%$ & $0.00 \%$ & $0.00 \%$ \\
\hline Timur & $0.00 \%$ & $0.00 \%$ & $0.00 \%$ & $0.00 \%$ & $0.00 \%$ & $0.00 \%$ \\
\hline$\underline{\text { Tenggara }}$ & $1.52 \%$ & $12.12 \%$ & $0.00 \%$ & $0.00 \%$ & $0.00 \%$ & $13.64 \%$ \\
\hline Selatan & $2.27 \%$ & $26.52 \%$ & $0.00 \%$ & $0.00 \%$ & $0.00 \%$ & $28.79 \%$ \\
\hline $\begin{array}{l}\text { Barat } \\
\text { Daya }\end{array}$ & $1.52 \%$ & $37.88 \%$ & $0.00 \%$ & $0.00 \%$ & $0.00 \%$ & $39.39 \%$ \\
\hline Barat & $0.00 \%$ & $13.64 \%$ & $0.00 \%$ & $0.00 \%$ & $0.00 \%$ & $13.64 \%$ \\
\hline $\begin{array}{l}\text { Barat } \\
\text { Laut }\end{array}$ & $0.76 \%$ & $1.52 \%$ & $0.00 \%$ & $0.00 \%$ & $0.00 \%$ & $2.27 \%$ \\
\hline
\end{tabular}

\section{HASIL DAN PEMBAHASAN}

\section{Analisis Angin}

Data angin diperoleh dari Stasiun Metereologi Kelas I Frans Kaisiepo Biak tahun 2008-2018.

Tabel 1. Rekapitulasi persentase frekuensi angin yang terjadi

Dari mawar angin yang diperoleh, angin datang dominan berasal dari arah Barat Daya. Kecepatan angin terbesar berulang kali terdapat di bulan Februari tahun 2008. Hasil pengolahan data angin dengan windrose dapat dilihat pada Gambar 3. 


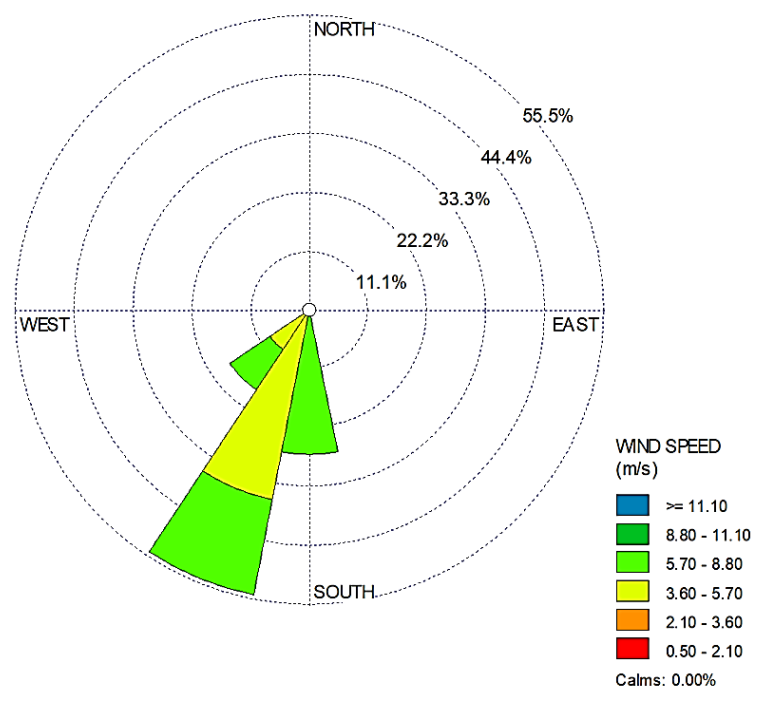

Gambar 3. Hasil pengolahan data angin dengan windrose

\section{Analisis Gelombang}

Fetch

Diperlukan bantuan aplikasi Autocad dan google earth untuk menggambarkan daerah pembangkitan gelombang dari lokasi penelitian yaitu di Desa Padaido.

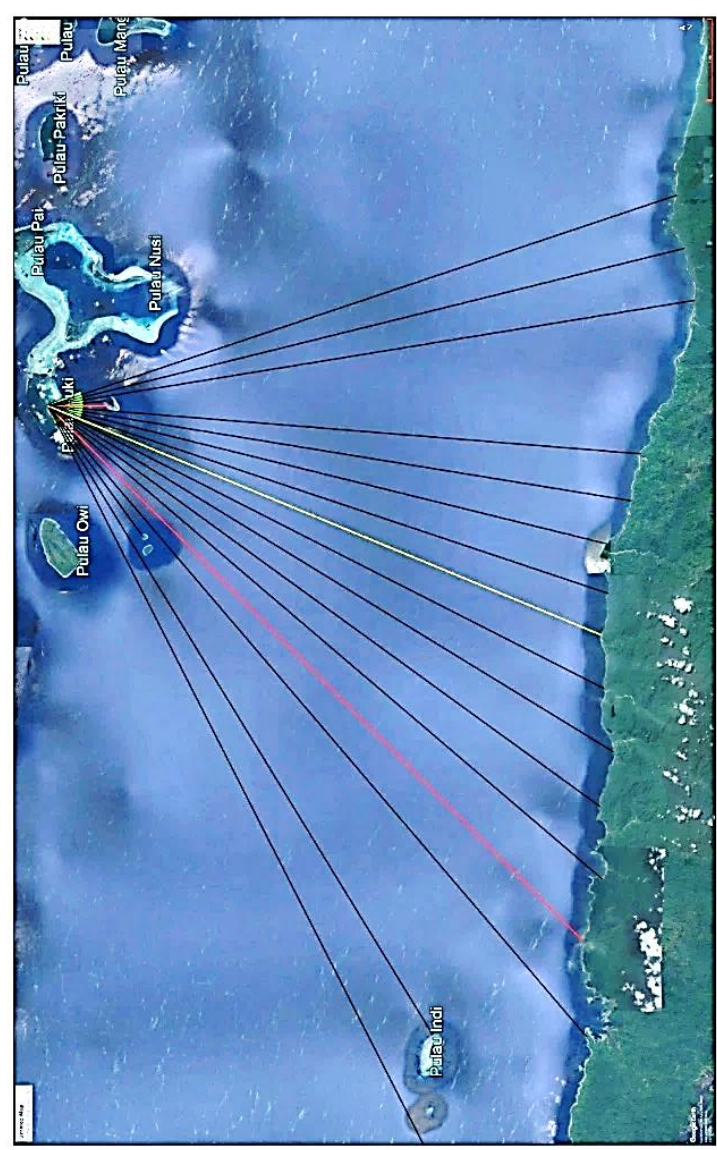

Gambar 4. Fetch peta lokasi
Tabel 2. Pengukuran fetch lokasi penelitian

\begin{tabular}{|c|c|c|c|c|c|}
\hline \multirow{2}{*}{$\alpha\left({ }^{\circ}\right)$} & \multirow{2}{*}{$\operatorname{Cos}(\alpha)$} & \multicolumn{2}{|c|}{ Panjang Fetch Xi (km) } & \multicolumn{2}{|c|}{$\mathrm{Xi} \operatorname{Cos} \alpha$} \\
\hline & & Selatan & Barat Daya & Selatan & Barat Daya \\
\hline 20 & 0.940 & 56.226 & 52.923 & 52.835 & 49.731 \\
\hline 15 & 0.966 & 55.620 & 56.248 & 53.725 & 54.331 \\
\hline 10 & 0.985 & 55.552 & 57.869 & 54.708 & 56.990 \\
\hline 5 & 0.996 & 4.890 & 61.834 & 4.871 & 61.599 \\
\hline 0 & 1.000 & 5.320 & 64.112 & 5.320 & 64.112 \\
\hline-5 & 0.996 & 50.430 & 70.384 & 50.238 & 70.116 \\
\hline-10 & 0.985 & 50.125 & 13.714 & 49.363 & 13.506 \\
\hline-15 & 0.966 & 48.802 & 62.554 & 47.139 & 60.423 \\
\hline-20 & 0.940 & 50.125 & 200.000 & 47.102 & 187.939 \\
\hline Total & 8.773 & & & 365.302 & 618.746 \\
\hline
\end{tabular}

Perhitungan fetch rata - rata dengan menggunakan persamaan (6) diperoleh untuk arah selatan 41638,2 $\mathrm{m}$ dan arah barat daya $70526,5 \mathrm{~m}$

\section{Koreksi data angin}

Untuk pembangkitan gelombang, diperlukan koreksi data angin. Data angin yang akan digunakan diubah dari satuan knot ke satuan $\mathrm{m} / \mathrm{s}$ agar lebih mudah dalam mengolah data. Data angin yang digunakan adalah data angin yang mempunyai nilai yang paling besar setiap tahun.

Tabel 3. Koreksi data angin

\begin{tabular}{|c|c|c|c|}
\hline \multirow{2}{*}{ Tahun } & \multirow{2}{*}{ Bulan } & \multicolumn{2}{|c|}{ Kecepatan } \\
\cline { 3 - 4 } & & Knot & $\mathbf{~ m / s}$ \\
\hline 2008 & Februari & 18 & 9.252 \\
\hline \multirow{2}{*}{2009} & Januari & 9 & 4.626 \\
\cline { 2 - 4 } & Maret & 9 & 4.626 \\
\hline 2010 & Agustus & 7 & 3.598 \\
\hline 2011 & Februari & 11 & 5.654 \\
\hline 2012 & Januari & 12 & 6.168 \\
\hline 2013 & Februari & 9 & 4.626 \\
\hline 2014 & Juli & 5 & 2.570 \\
\hline 2015 & Oktober & 12 & 6.168 \\
\hline 2016 & Mei & 11 & 5.654 \\
\hline 2017 & Maret & 16 & 8.224 \\
\hline 2018 & September & 7 & 3.598 \\
\hline
\end{tabular}

Pengukuran data angin tidak berada pada ketinggian $10 \mathrm{~m}$, maka dilakukan koreksi data dengan menggunakan persamaan (1), diperoleh $. U_{10}=$ 10,988

Koreksi stabilitas dan koreksi lokasi diperlukan dalam menghitung kecepatan angin laut yang dikoreksi terhadap angin darat. Untuk koreksi stabilitas, digunakan $R_{T}=1,1$ dikarenakan data suhu tidak terdapat pada data angin dan untuk koreksi lokasi $\left(R_{L}\right)$ digunakan nilai berdasarkan grafik SPM untuk perbandingan kecepatan angin laut dan angin darat 
Perhitungan terhadap koreksi stabilitas dan lokasi berdasarkan persamaan (2) diperoleh $U=$ $14,505 \mathrm{~m} / \mathrm{s}$

Setelah mengoreksi kecepatan angin maka langkah selanjutnya adalah mengkonversi kecepatan angin menjadi wind stress factor (Ua) dengan menggunakan persamaan 3.

Untuk perhitungan konversi, diambil data angin terbesar di setiap tahun dan hasil perhitungan selanjutnya ditampilkan pada Tabel 4 .

Tabel 4. Konversi kecepatan angin ke wind stress factor

\begin{tabular}{|c|c|c|c|c|}
\hline \multirow{2}{*}{ Tahun } & \multirow{2}{*}{ Bulan } & $\mathbf{U 1 0}$ & $\mathbf{U}$ & $\mathbf{U a}$ \\
\cline { 3 - 5 } & & $\mathbf{m} / \mathbf{s}$ & $\mathbf{m} / \mathbf{s}$ & $\mathbf{~ m} / \mathbf{s}$ \\
\hline 2008 & Februari & 10.988 & 14.505 & 19.051 \\
\hline \multirow{2}{*}{2009} & Januari & 5.494 & 9.065 & 10.687 \\
\cline { 2 - 5 } & Maret & 5.494 & 9.065 & 10.687 \\
\hline 2010 & Agustus & 4.273 & 7.427 & 8.363 \\
\hline 2011 & Februari & 6.715 & 10.341 & 12.566 \\
\hline 2012 & Januari & 7.326 & 11.120 & 13.740 \\
\hline 2013 & Februari & 5.494 & 9.065 & 10.687 \\
\hline 2014 & Juli & 3.052 & 5.540 & 5.831 \\
\hline 2015 & Oktober & 7.326 & 11.120 & 13.740 \\
\hline 2016 & Mei & 6.715 & 10.341 & 12.566 \\
\hline 2017 & Maret & 9.767 & 13.753 & 17.843 \\
\hline 2018 & September & 4.273 & 7.427 & 8.363 \\
\hline
\end{tabular}

Perhitungan peramalan gelombang akan diuraikan dibawah ini dan diambil satu data sebagai contoh uraian pada bulan Februari tahun 2008:

Diketahui:

$\begin{array}{ll}\text { Ua } & =19,051 \mathrm{~m} / \mathrm{s} \\ \mathrm{t} & =10800 \text { detik } \\ \mathrm{g} & =9,81 \mathrm{~m} / \mathrm{s}^{2} \\ \text { Fetch Efektif } & =70526,5 \mathrm{~m}\end{array}$

Menentukan kondisi gelombang (Fully Developed dan Non-Fully Developed) dengan persamaan (9) gt $=10577,6$, karena $10577,6<7,15 \times 10^{4}$ maka termasuk Non-Fully Developed

Menentukan kondisi pembentukan gelombang (Duration Limited atau Fetch Limited) dengan menggunakan persamaan (13), $t_{c}=20541,395$ detik

Diperoleh $\mathrm{t}=10800<\mathrm{tc}_{\mathrm{c}}=20541,395$ maka kondisi pembentukan gelombang termasuk kondisi Duration Limited. Karena kondisi pembentukan gelombang yang didapatkan adalah Duration Limited maka perlu dihitung fetch minimumnya.

Perhitungan Fetch minimum $\left(F_{\text {min }}\right)$ dengan menggunakan persamaan (14), $F_{\min }=26887,051$ m.

Fetch minimum akan digunakan untuk mencari nilai tinggi gelombang di laut dalam dan periode gelombang.

Tinggi gelombang di laut dalam $\left(H_{m 0}\right)$ berdasarkan persamaan (19) diperoleh $H_{m 0}=1,596 \mathrm{~m}$ dan

Periode Gelombang $T_{p}=4,988$ detik

Jadi tinggi gelombang yang terjadi di laut dalam yang berdurasi 3 jam (10800 detik) pada bulan Februari tahun 2008 adalah 1,596 m dengan periode 4,988 detik.

Tabel 5. Peramalan gelombang laut dalam

\begin{tabular}{|c|c|c|c|c|}
\hline Tahun & Bulan & Ua & Hm0 & Tp \\
\hline 2008 & Februari & 19.051 & 1.596 & 4.988 \\
\hline \multirow{2}{*}{2009} & Januari & 10.687 & 0.775 & 3.736 \\
\cline { 2 - 5 } & Maret & 10.687 & 0.775 & 3.736 \\
\hline 2010 & Agustus & 8.363 & 0.570 & 3.305 \\
\hline 2011 & Februari & 12.566 & 0.949 & 4.051 \\
\hline 2012 & Januari & 13.740 & 1.061 & 4.236 \\
\hline 2013 & Februari & 10.687 & 0.775 & 3.736 \\
\hline 2014 & Juli & 5.831 & 0.363 & 2.760 \\
\hline 2015 & Oktober & 13.740 & 1.061 & 4.236 \\
\hline 2016 & Mei & 12.566 & 0.949 & 4.051 \\
\hline 2017 & Maret & 17.843 & 1.470 & 4.828 \\
\hline 2018 & September & 8.363 & 0.570 & 3.305 \\
\hline
\end{tabular}




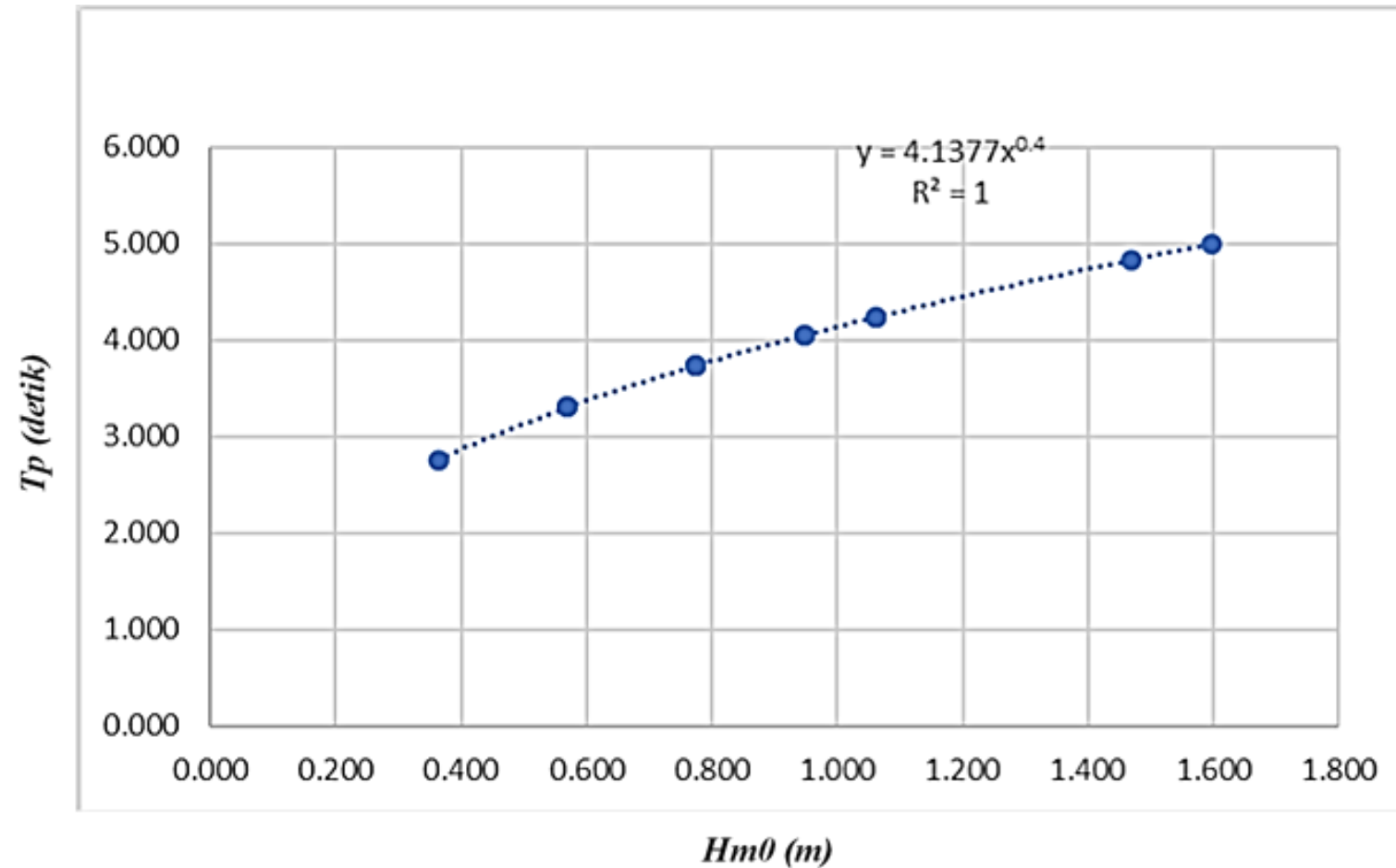

Gambar 5. Hubungan antara tinggi gelombang dan periode gelombang

\section{Gelombang Rencana}

Untuk menghitung tinggi gelombang dengan periode ulang diperlukan data gelombang signifikan $(\mathrm{Hs})$ yang didapatkan dari nilai rata - rata tinggi gelombang setiap tahunnya. Setelah mendapatkan tinggi signifikannya, maka tinggi gelombang pecah dengan periode ulang dihitung menggunakan metode distribusi Gumbell (Fisher - Tipped Type 1).

Tabel 6. Hasil perhitungan dengan metode Fisher- Tipped Type

\begin{tabular}{|c|c|c|c|c|c|c|c|c|c|}
\hline no & Hs & TP & $\mathrm{P}$ & $\mathrm{Ym}$ & $\mathrm{Hsm} . \mathbf{Y m}$ & $\mathbf{y}_{\mathbf{m}}{ }^{2}$ & $\left.\mathbf{( H}_{\mathbf{s m}}-\mathbf{H}_{\mathbf{r}}\right)^{\mathbf{2}}$ & $\overline{\mathbf{H}_{\mathbf{s m}}}$ & $\mathbf{H}_{\mathbf{s m}}-\mathbf{H}_{\mathbf{s m}}$ \\
\hline 1 & 1.596 & 4.988 & 0.950 & 2.963 & 4.728 & 8.778 & 0.455 & 1.667 & -0.071 \\
\hline 2 & 1.470 & 4.828 & 0.860 & 1.889 & 2.778 & 3.570 & 0.301 & 1.336 & 0.134 \\
\hline 3 & 1.061 & 4.236 & 0.770 & 1.341 & 1.422 & 1.798 & 0.019 & 1.167 & -0.106 \\
\hline 4 & 1.061 & 4.236 & 0.680 & 0.952 & 1.010 & 0.907 & 0.019 & 1.047 & 0.013 \\
\hline 5 & 0.949 & 4.051 & 0.590 & 0.639 & 0.606 & 0.408 & 0.001 & 0.951 & -0.002 \\
\hline 6 & 0.949 & 4.051 & 0.500 & 0.367 & 0.348 & 0.134 & 0.001 & 0.867 & 0.082 \\
\hline 7 & 0.775 & 3.736 & 0.410 & 0.115 & 0.089 & 0.013 & 0.022 & 0.790 & -0.015 \\
\hline 8 & 0.775 & 3.736 & 0.320 & -0.130 & -0.101 & 0.017 & 0.022 & 0.714 & 0.061 \\
\hline 9 & 0.570 & 3.305 & 0.230 & -0.384 & -0.219 & 0.148 & 0.123 & 0.636 & -0.066 \\
\hline 10 & 0.570 & 3.305 & 0.140 & -0.675 & -0.385 & 0.456 & 0.123 & 0.546 & 0.024 \\
\hline 11 & 0.363 & 2.760 & 0.050 & -1.095 & -0.398 & 1.199 & 0.312 & 0.417 & -0.054 \\
\hline Total & 10.137 & & 5.500 & 5.982 & 9.878 & 17.428 & 1.398 & 10.137 & 0.000 \\
\hline Rata-Rata & 0.922 & 3.930 & 0.500 & 0.544 & 0.898 & 1.584 & 0.127 & 0.922 & 0.000 \\
\hline
\end{tabular}

Tabel 7. Hasil perhitungan tinggi gelombang signifikan

\begin{tabular}{|c|c|c|c|c|c|c|}
\hline $\begin{array}{c}\text { Periode } \\
\text { ulang } \\
\text { (tahun) }\end{array}$ & $\mathbf{y}_{\mathbf{r}}$ (tahun) & $\mathbf{H}_{\mathbf{s r}}(\mathbf{m})$ & $\sigma_{\mathbf{n r}}$ & $\sigma_{\mathbf{r}}$ & $\begin{array}{c}\mathbf{H}_{\mathbf{s}}-\mathbf{1 , 2 8 \sigma _ { \mathbf { r } }} \\
(\mathbf{m})\end{array}$ & $\begin{array}{c}\mathbf{H}_{\mathbf{s}}+\mathbf{1 , 2 8 \sigma _ { \mathbf { r } }} \\
(\mathbf{m})\end{array}$ \\
\hline 2 & 0.367 & 0.867 & 0.320 & 0.120 & 0.714 & 1.020 \\
\hline 5 & 1.500 & 1.216 & 0.535 & 0.200 & 0.960 & 1.472 \\
\hline 10 & 2.250 & 1.447 & 0.728 & 0.272 & 1.099 & 1.796 \\
\hline 25 & 3.199 & 1.739 & 0.989 & 0.370 & 1.266 & 2.213 \\
\hline 50 & 3.902 & 1.956 & 1.188 & 0.444 & 1.388 & 2.524 \\
\hline 100 & 4.600 & 2.171 & 1.387 & 0.519 & 1.507 & 2.835 \\
\hline
\end{tabular}


Penentuan tinggi dan kedalaman gelombang pecah

Setelah mengetahui tinggi gelombang rencana signifikan $\left(H_{s r}\right)$ selanjutnya menghitung tinggi gelombang ekivalen dalam perhitungan gelombang pecah.

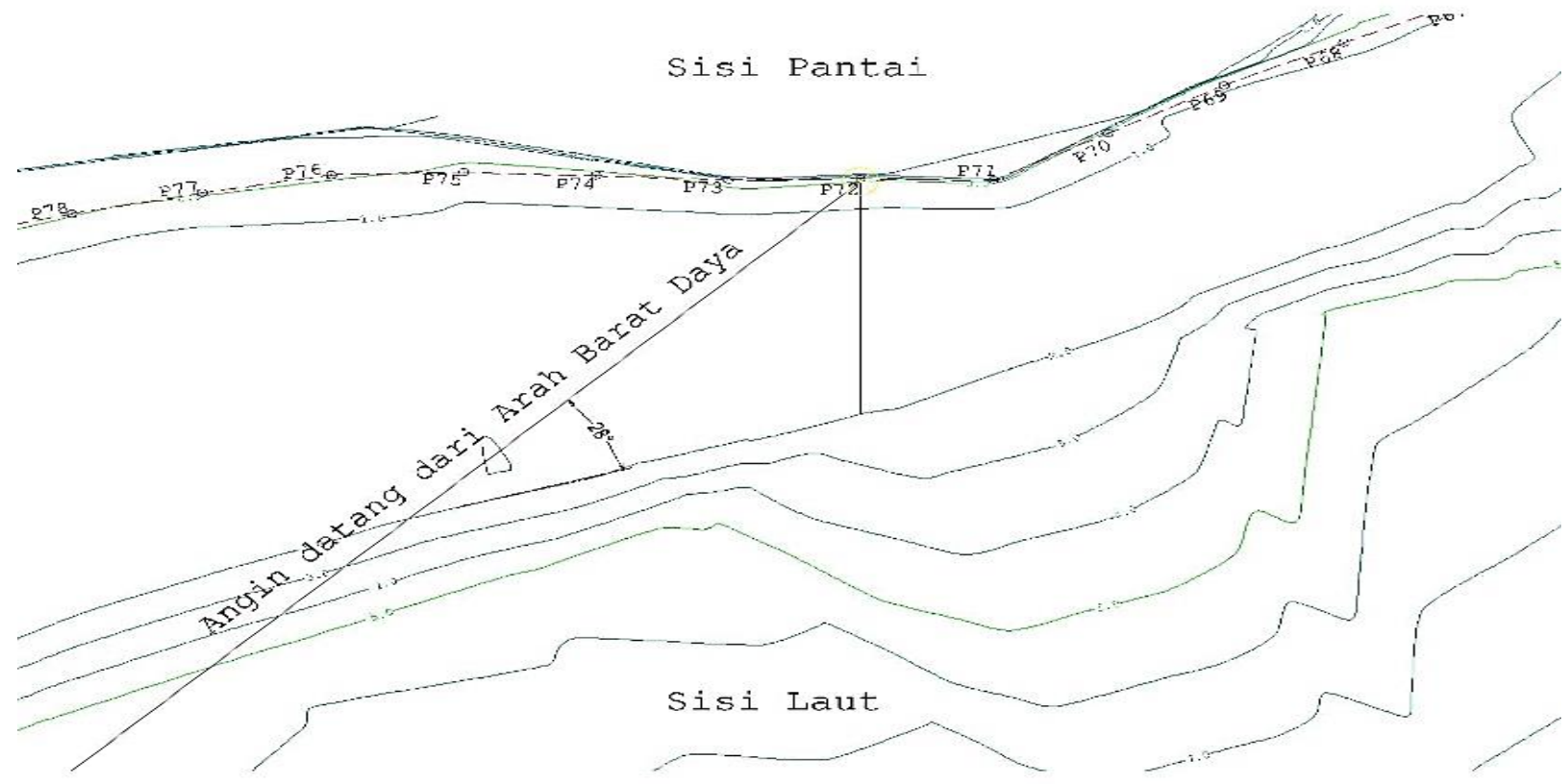

Gambar 6. Sudut datang gelombang

Tabel 8. Hasil perhitungan tinggi dan kedalaman gelombang pecah periode ulang

\begin{tabular}{|c|c|c|c|c|c|c|c|c|c|c|c|}
\hline $\begin{array}{c}\text { Periode } \\
\text { ulang } \\
\text { (tahun) }\end{array}$ & $\begin{array}{c}\mathrm{Hs}+ \\
\mathbf{1}, 28 \mathrm{sr} \\
(\mathrm{m})\end{array}$ & $\mathrm{a}$ & $\mathrm{b}$ & $\mathrm{T}$ & $\mathrm{L} 0$ & $\mathrm{a} 0$ & $\mathrm{Kr}$ & $\mathrm{Ks}$ & $\mathrm{H}+0$ & $\mathrm{Hb}$ & $\mathrm{db}$ \\
\hline 2 & 1.020 & 6.387 & 0.843 & 4.171 & 27.142 & 28 & 0.939 & 1.307 & 1.252 & 1.058 & 1.297 \\
\hline 5 & 1.472 & 6.387 & 0.843 & 4.830 & 36.391 & 28 & 0.939 & 1.307 & 1.807 & 1.490 & 1.856 \\
\hline 10 & 1.796 & 6.387 & 0.843 & 5.229 & 42.662 & 28 & 0.939 & 1.307 & 2.204 & 1.793 & 2.261 \\
\hline 25 & 2.213 & 6.387 & 0.843 & 5.685 & 50.416 & 28 & 0.939 & 1.307 & 2.716 & 2.179 & 2.791 \\
\hline 50 & 2.524 & 6.387 & 0.843 & 5.993 & 56.025 & 28 & 0.939 & 1.307 & 3.098 & 2.464 & 3.195 \\
\hline 100 & 2.835 & 6.387 & 0.843 & 6.278 & 61.476 & 28 & 0.939 & 1.307 & 3.480 & 2.746 & 3.604 \\
\hline
\end{tabular}

\section{Penentuan zona gelombang pecah}

Untuk Periode Ulang 50 Tahun Dengan tinggi gelombang pecah $\left(H_{b}\right)=2,464 \mathrm{~m}$ dan kedalaman $\left(d_{b}\right)$ $=3,195 \mathrm{~m}$.

Pada kondisi $S W L=0,15 \mathrm{~m}$ maka,

Elevasi dasar laut $=\mathrm{LWL}-d_{b}=0,15-3,195=-3,045$ $\mathrm{m}$

Pada kondisi $\mathrm{HWL}=2,21 \mathrm{~m}$ maka,

Elevasi dasar laut $=\mathrm{HWL}-d_{b}=2,21-3,195=-0,985$ $\mathrm{m}$

Perhitungan perencanaan pemecah gelombang
Pemecah gelombang sisi miring mempunyai sifat fleksibel. Kerusakan yang terjadi karena serangan gelombang tidak secara tiba - tiba (tidak fatal).

Didapatkan nilai $H_{b}=2,464 m$ dan $d_{b}=3,195 m$ pada peride ulang 50 tahun.

Elevasi puncak pemecah gelombang dihitung dengan persamaan (30) dengan kemiringan sisi pemecah gelombang diambil 1:2., $I_{r}=2,424$ dan $R_{u}=2,621 \mathrm{~m}$

Jenis lapis lindung yang pertama digunakan jenis batu pecah. Dihitung elevasi puncak pemecah gelombang dengan memperhitungkan tinggi kebebasan $0,5 \mathrm{~m}$.

$E l_{\text {Pem.Gel }}=H W L+R_{u}+$ tinggi kebebasan 
$E l_{\text {Pem.Gel }}=0,985+2,621+0,5$

$E l_{\text {Pem.Gel }}=4,106 \mathrm{~m}$

Untuk lapis lindung Tetrapod:

$\frac{R_{u}}{H}=0,755$

$R_{u}=0,755 \times 2,383=1,799 \mathrm{~m}$

$E l_{\text {Pem.Gel }}=H W L+R_{u}+$ tinggi kebebasan

$E l_{\text {Pem.Gel }}=0,985+1,799+0,5$

$E l_{\text {Pem.Gel }}=3,284 \mathrm{~m}$

Untuk tinggi pemecah gelombang:

$H_{\text {Pem.Gel }}=E l_{\text {Pem.Gel }}-E l_{\text {Dsr.Laut }}$

$H_{\text {Pem.Gel }}=4,106-(-3,08)=7,186 m$ (untuk lapis batu pecah)

$H_{\text {Pem.Gel }}=3,284-(-3,08)=6,364 m$ (untuk lapis Tetrapod)

Karena di dekat lokasi pekerjaan banyak terdapat batu pecah, maka akan digunakan batu pecah sebagai bahan yang memiliki berat jenis $\left(1,45 \mathrm{~kg} / \mathrm{m}^{3}\right)$. Uraian perhitungan sebagai berikut $\left(K_{D}=2,4\right)$ :

Dengan menggunakan persamaan (31) dan (32) diperoleh $\mathrm{Sr}=1,411$ dan $\mathrm{W}=127,132$ ton.

Didapat nilai $\mathrm{n}=2 ; k_{\Delta}=1,02$ maka lebar puncak pemecah gelombang diuraikan sebagai berikut:

$B=n k_{\Delta}\left(\frac{W}{\gamma_{r}}\right)^{1 / 3}$

$B=2 \times 1,02\left(\frac{127,132}{1,45}\right)^{1 / 3}$

$B=9,063 \mathrm{~m}$

Tebal lapis lindung sebesar

$t=n k_{\Delta}\left(\frac{W}{\gamma_{r}}\right)^{1 / 3}$

$t=1 \times 1,02\left(\frac{127,132}{1,45}\right)^{1 / 3}$

$t=4,531 \mathrm{~m}$

Untuk gambar dimensi pemecah gelombang, dapat dilihat potongan melintang pada Gambar 7 .

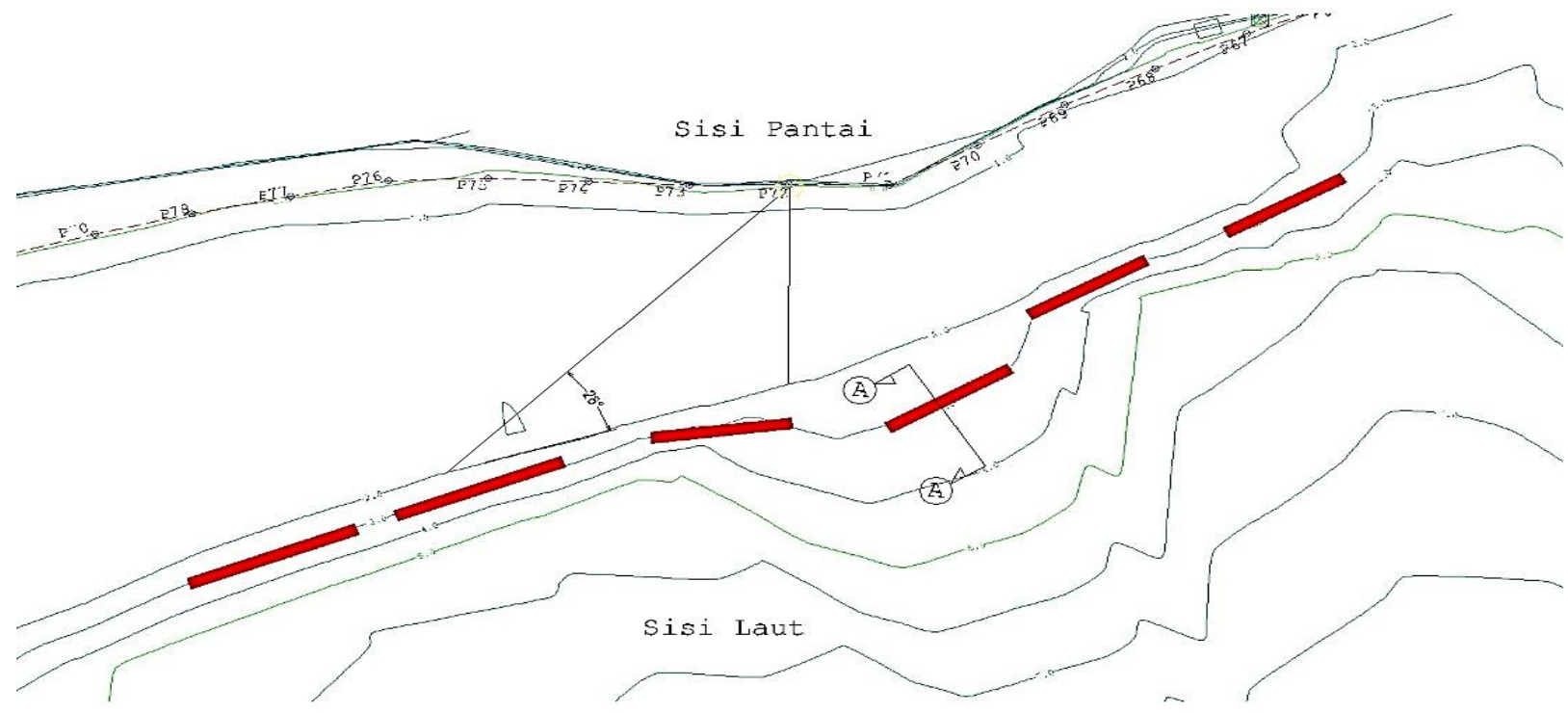

Gambar 7. Lokasi pemecah gelombang

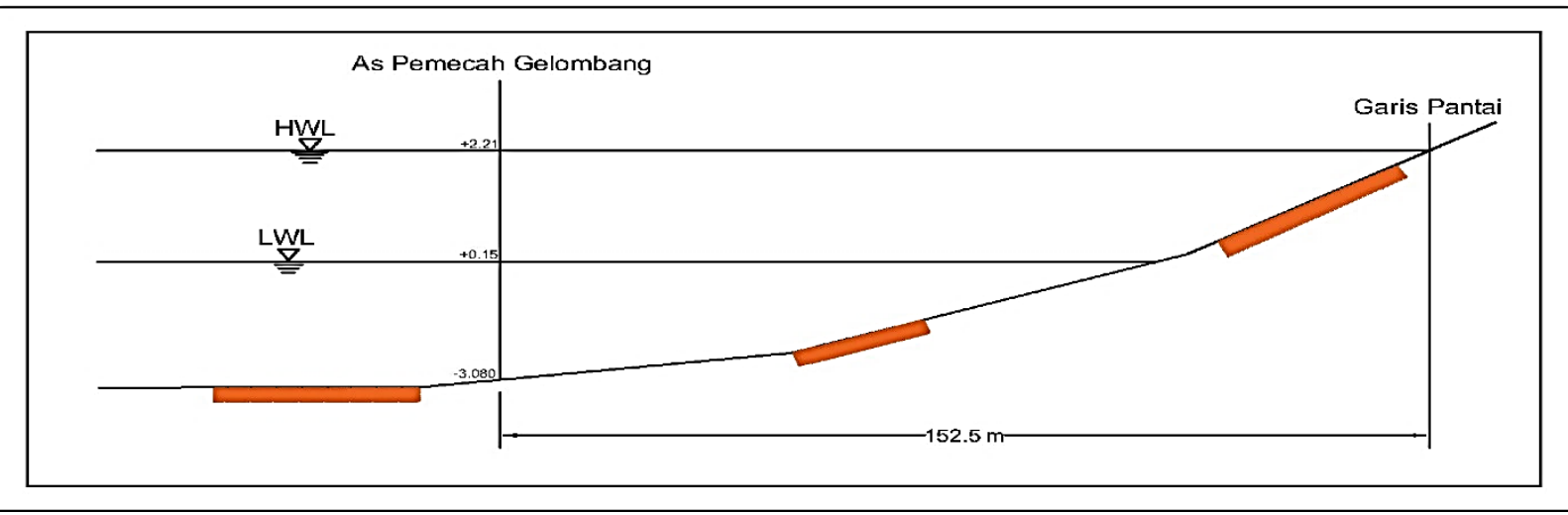

Gambar 8. Lokasi pemecah gelombang (Breakwater) Pot A-A 


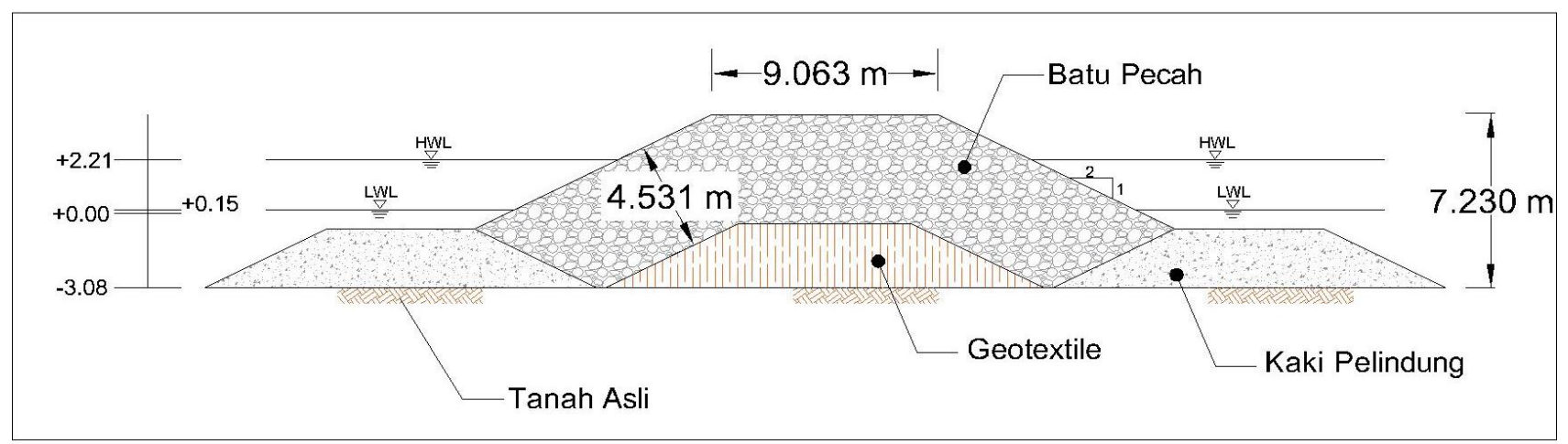

Gambar 9. Hasil perancangan dimensi pemecah gelombang

\section{Pembahasan}

Dimensi pemecah gelombang sisi miring sebagai berikut:

$$
\begin{array}{ll}
H_{S} & =2,383 \mathrm{~m} \\
d_{S} & =3,080 \mathrm{~m} \\
H_{\text {pem.gel }} & =7,186 \mathrm{~m} \text { (untuk lapis lindung batu pecah) } \\
B & =9,063 \mathrm{~m} \\
t & =4,531 \mathrm{~m}
\end{array}
$$

\section{KESIMPULAN}

Karakteristik angin yang datang ke Pantai Auki sebagian besar berasal dari arah Barat Daya dan kecepatan angin paling besar secara berulang berada pada bulan Februari 2008.

\section{DAFTAR PUSTAKA}

[1] Sri W., Haryono, dan Bety P, 2011, "Perencanaan Bangunan Pemecah Gelombang Untuk Perencanaan Pelabuhan Teluk Sololo Kepulauan Halmahera Maluku", Jurnal Imliah Desain dan Konstruksi Vol.10, no.1

[2] D. A. Karima dan B. Sarwono, 2017, "Perencanaan Bangunan Pemecah Gelombang di Teluk Sumbreng, Kabupaten Trenggalek," Jurnal Tek.ITS, Vol. 6, no. 2, doi: 10.12962/j23373539.v6i2.26701.

[3] Restu W., Bambang,A,P., dan Shandi.I.S., 2018, "Perencanaan Pemecah Gelombang Sisi Miring di Pelabuhan Merak Dengan Menggunakan Batu Pecah dan Tetrapod", Fondasi : Jurnal Teknik
Karakteristik gelombang pada periode ulang 50 tahun, tinggi gelombang pecah $\left(H_{b}\right)$ pada daerah bangunan adalah 2,464 $\mathrm{m}$ dan kedalaman gelombang pecah $\left(d_{b}\right)=3,195 \mathrm{~m}$. Zona gelombang pecah berada pada elevasi $-3,045 \mathrm{~m}$ sampai dengan $-0,985 \mathrm{~m}$.

Pemecah gelombang yang digunakan adalah pemecah gelombang sisi miring. Pemasangan pemecah gelombang berada pada kedalaman $d_{s}=$ $3,08 \mathrm{~m}$ dan pada saat tinggi gelombang $\left(H_{s}\right)=$ $2,383 \mathrm{~m}$. Dengan lebar punc ak pemecah gelombang $B=9,063 \mathrm{~m}$, tinggi pemecah gelombang $H=$ $7,186 \mathrm{~m}$ (untuk lapis batu pecah) dan tebal lapisan utama $(t)=4,531 \mathrm{~m}$

$$
\begin{array}{lrr}
\text { Sipil, } & \text { Vol.7, } & \text { no.2.doi } \\
\text { http://dx.doi.org/10.36055/jt.v7i2.4078 }
\end{array}
$$

[4] Gunawan, 2014, "Analisis Gelombang Terhadap Struktur Bangunan Breakwater Tegak Pantai Tapak Paderi Bengkulu", Jurnal Teknik Sipil; Inersia, Vol.6, no.2, doi: 10.33369/ijts.6.2.21-30

[5] I. Ichsan dan A. H. Suleman, 2018, "Analisis Perencanaan Break Water Dalam Penanganan Sedimentasi Pantai Di Desa Botubarani," Gorontalo J. Infrastruct. Sci. Eng., vol. 1, no. 1, , doi: 10.32662/gojise.v1i1.158.

[6] I Gede A.W.P., 2018, "Perencanaan Bangunan Pemecah Gelombang Tipe Groin Dengan Bahan Tetrapod di Pantai Jasri, Kabupaten Karangasem", Paduraksa, Vol.7, no.2, doi: https://doi.org/10.22225/pd.7.2.943.138-149 